\title{
THE ROLE AND LIMITATIONS OF THE UNMANNED AERIAL VEHICLE IN THE PRECISION SMALL AND MIDDLE-SIZE CROP PRODUCTION
}

\section{A PILÓTA NÉLKÜLI LÉGI JÁRMÜ SZEREPE ÉS KORLÁTAI A KIS- ÉS KÖZEPES MÉRETÜ PRECÍZIÓS NÖVÉNYTERMESZTÉSBEN}

\author{
LÁSZLOP ÁDÁM, egyetemi oktató \\ Pázmány Péter Katolikus Egyetem \\ adam.laszlop@yahoo.de
}

DOI 10.47273/AP.2020.21.29-40

\begin{abstract}
Internet of Things (IoT) could prove significantly potential in precision farming, facilitating the acquisition of real-time crop's, soil, and environmental data through the use of Unmanned Aerial Vehicles (UAVs) with their capabilities to capture high spatial and temporal resolution imagery. The effective deployment of such vehicles and linking them with on-farm sensors can transform agriculture that would allow it to move into the next era of agriculture. The Precise data collection can enable small and middle-size growers to make planting decisions well ahead of time and follow the cultural practices based on the model extracted from the data collected for the multiple factors from their farm locations. This data can significantly help farmers while making quick decisions, reducing agricultural inputs costs such as seeds, insecticides, and fertilizers, and can boost agricultural production. We will also look into different roles that UAVs can perform in precision farming and their limitations in line with recent EU Directives (EU) 2019/947 and (EU) 2019/945 on the rules and procedures for the operation of Unmanned Aircraft in the European Union air space. We will also review the entire range of precision farming practices that can help farmers taking full advantage of the available technology for automating farming practices that save their time and money with accuracy, effectively.
\end{abstract}

\begin{abstract}
ABSZTRAKT
A tárgyak internete (angolul: Internet of Things, IoT) jelentős potenciálnak bizonyulhat a precíziós gazdálkodásban, megkönnyítve a növényekre, talajra és környezetre vonatkozó valós idejü adatok megszerzését pilóta nélküli légi jármüvek (UAV) felhasználásával, amelyek képesek nagy térbeli és időbeli felbontású képek rögzítésére. Az ilyen jármüvek hatékony bevezetése és a gazdasági területeken lévő szenzorokkal való összekapcsolás átalakíthatja a
\end{abstract}


mezőgazdaságot, amely lehetővé teheti a mezőgazdaság következő korszakába való belépést. A precíziós adatgyüjtés lehetővé teheti a kis- és közepes méretü termelők számára, hogy már jóval elöre meghozzák a telepítési döntéseket, és azon modell alapján gyakorolhassák a müvelést, melyet a müvelési területeik különböző tényezői szerint gyüjtött adatokból nyertek. Ezek az adatok jelentősen segíthetik a gazdálkodókat a gyors döntések meghozatalában, csökkenthetik az olyan mezőgazdasági ráfordítások költségeit, mint például a vetőmagok, rovarirtók és mütrágyák, továbbá fellendíthetik a mezőgazdasági termelést. $\mathrm{Az}$ is megvizsgálásra kerül, hogy a pilóta nélküli repülögépek európai uniós légtérben történő üzemeltetésének szabályairól és eljárásairól szóló legutóbbi (EU) 2019/947 és (EU) 2019/945 irányelveknek megfelelöen milyen különféle szerepeket tölthetnek be a precíziós gazdálkodásban az UAV-ok, illetve melyek ezek korlátai. Áttekintésre kerül továbbá a precíziós gazdálkodási gyakorlatok teljes skáláját is, amelyek segíthetnek a gazdálkodóknak, hogy teljes mértékben kihasználják a rendelkezésre álló technológiát az olyan gazdálkodási gyakorlatok automatizálására, amelyek pontosan és hatékonyan spórolják meg idejüket és pénzüket.

\section{Introduction}

Agriculture is revolutionizing for the last ten years in the wake of the high food demand with an increase in the world population that expects to reach 9.1 billion by 2050 , to compensate at least $70 \%$ of the increase in food production could only meet the need of this over-grown population (FAO, 2009).. The agriculture farming industry is facing several severe concerns over increased prices of farm inputs, labor shortages, and climate change at one end, and, at the other end, conventional farming and lack of farming skills hinder agriculture production reach its optimum level. Together, these limitations making agriculture an impracticable and unproductive industry, especially in low-income countries in South East Asia and Sub-Saharan Africa. These elements together need the intervention of the most advanced technologies in agriculture, such as digitalizing the aspects of growing crops, automating farm growth factors, and collecting on-farm soil and environmental data to use them in a pre-decisive practice that could help to boost agriculture production. A positive output can be achieved with the induction of COTS drones in the agriculture field that can perform several roles when deployed, effectively, and can provide a sweet alternative to unskilled or deficient labor along with saving a lot of money that otherwise goes wasted due to the overutilization of valuable resources and inputs. Furthermore, these UAVs are also capable of acquiring useful data that leads to measure crop vegetative index, monitors crops' growth, evaluates soil moisture level, and indicates the prevalence of pests and diseases along with spray fertilizers and insecticides precisely (J.V. Stafford, 2000). Drones also provide useful insights on the cropping patterns and crop rotations and can allow growers to aerially seed crops in lesser time. Moreover, these flying machines are capable of controlling remote irrigation practices, field mapping, and livestock 
monitoring. The use of agriculture drones can prove an economical option for capturing field and soil-related data compared to the satellite and Manned aerial vehicles that need typical weather conditions for gathering data. The efficiency of UAVs is much higher and they can perform crop spraying jobs 50-60\% faster, saving 50\% insecticides. Also, they have a very important role in irrigation scheduling and can save irrigation water between 30-50\% (Wright, 2016).

Due to the UAVs' inbuilt capabilities for precision farming and automation, the agriculture drones market is rising at a CAGR of $31.1 \%$ and is expected to grasp $\$ 5.19$ billion by 2025 (Meticulous Research, 2020). This triggering growth may have some linkages with the Pandemic as well since it put agriculture production under pressure due to lack of labor, transport, and skilled farmworkers in the areas of extreme pervasiveness. Additionally, an increase in the food demand for population fluxes and associated financing to increase the capabilities of drones for making them a more useful tool in automation and digitalization is proving UAVs more effective weaponry in the entire field related practices for precision agriculture. However, some technical specification and regulation may hinder their market growth in the European Union. But, as far as the security and privacy of the public are concerned, the EU directives (EU) 2019/947, and (EU) 2019/945 can enforce UAVs operators to build and fly machines that only comply with procedures and practices as outlined in these directives. One Delegated Act (EU) 2019/945, and one Implementing act (EU) 2019/947 describe the rules for the use and manufacturing of UAVs for European Union member states (EU 2019 a, b). The delegated act deals with the technical specification for the design and manufacturing of UAVs. The UAVs need to comply with the technical aspects and requirements to acquire approval from the authority. These requirements are based on the category and classes of UAVs (Figure 1). UAVs divide further into three classes. UAVs' further classification depends on their ability to take height, weight carrying capacity, distance from the public, and opportunity to drop weight that they could carry. Based on these capabilities UAVs are placed into 'open', 'specific', and 'certified' classes. The majority of agriculture drones will probably fall in the open class since the regulations for operators in this class is less severe than the rest of the classes. 
Figure 1: A visual representation of the adopted three categories of UAV operations

(A. Konert et al. 2020)

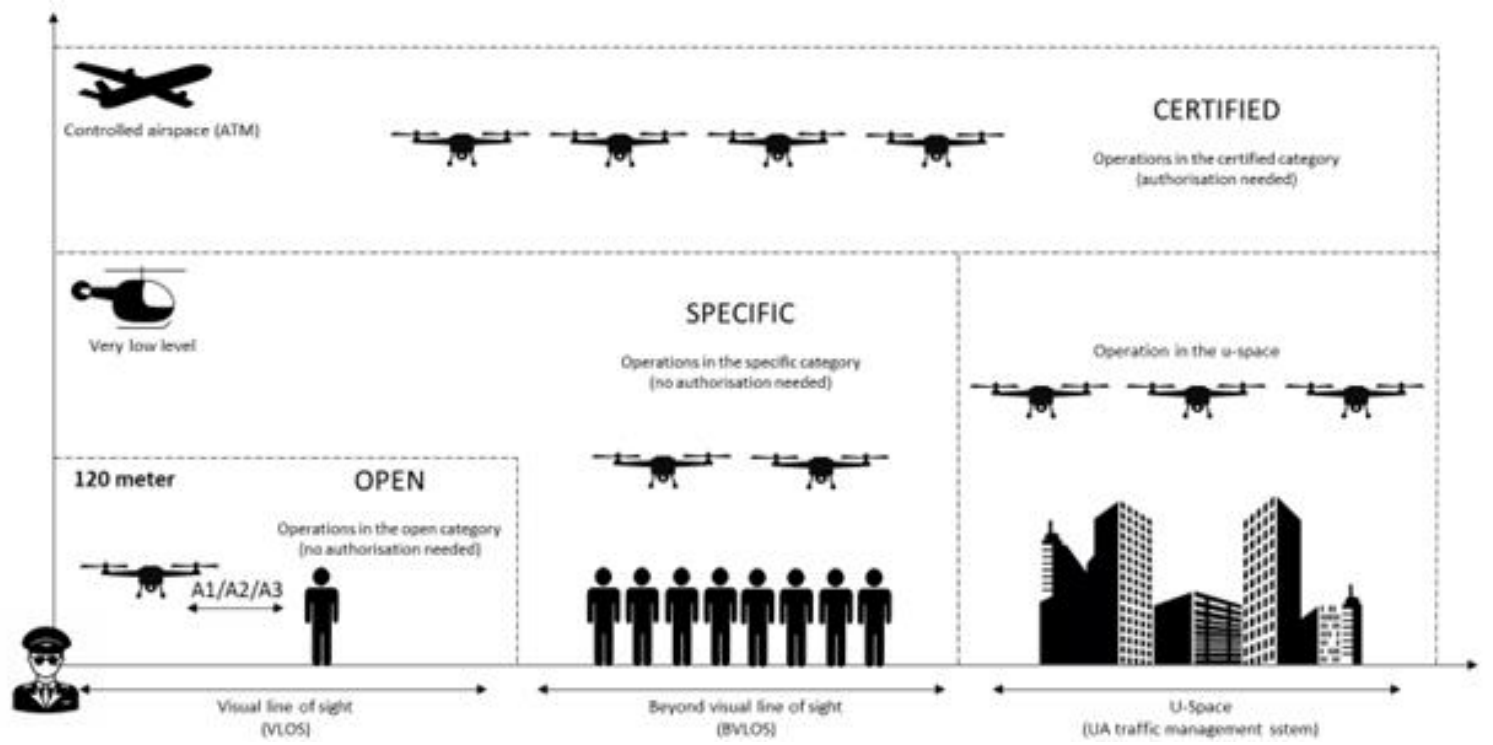

We can assume that these restrictions will improve the quality, as well as, the capabilities of agriculture UAVs to meet food production targets in the European Union. It will also help in automating on-farm crops' need to make precision agriculture their top choice. In this paper, we will review the most advanced studies on UAVs, related applications, sensors, and the techniques that can help to automate the small and middle-size food production programs to apply in precision agriculture.

\section{Important Tools for Precision Agriculture}

\subsection{Remote sensing}

Remote sensing is one of the most important technologies in Precision Agriculture and Digital Farming. Its capacities extent from monitoring field crops and vegetative index at different growth stages to measure soil health and moisture conditions through image capturing from various altitudes and broader wavelengths (Mulla, 2013). Previously, only satellites were capable of using remote sensing through the image captured from very high altitudes (Bauer ,1973 \& Mora, 2017) or Manned aircraft were among the other options to capture images for monitoring crop health and status. Both satellite and manned aircrafts imagery possess low spatial resolution, also there are restrictions for getting temporal resolution as the satellites, and Manned aircraft are dependent on weather conditions and their availability in the desired time frame. Moreover, the associated costs are also very high to capture images from such machines. The UAVs' remote sensing is pretty easy and fast in getting both spatial and temporal resolutions compared to previously adopted technologies due to low altitude flying and getting ultra-high spatial resolution imagery. Moreover, UAVs can be used when and where necessary 
depending on the need and purpose. Additionally, UAVs are simple to operate and deploy and could sense large fields in a short time without leaving any harm to humans and the environment. At present, there are several agricultural applications and sensors that UAVs can carry for monitoring crop production and cropping patterns, (Zhang, 2012) while some applications are used for monitoring environmental data (Manfreda, 2018). According to (Adão, 2017), hyperspectral imagery is also a powerful tool for this purpose (Maes et al., 2019) also highlight the suitability of the available sensors for each application from the perspective of UAVs in Precision Farming.

\subsection{Vegetative Index Mapping}

Vegetative index mapping practices replicate the cutting-edge remote sensing techniques. Vegetation index mapping includes the merging of hyperspectral and multispectral imagery for mining vegetative cover. If the multispectral imagery compromises the dozens of spectral bands, the hyperspectral imagery delivers hundreds of them. Hyperspectral sensors costume sound for vegetation mapping for the boosted reflection and absorption of spectral symbols from individual and complex groups would well discriminate using broader spectral bands. In this dominion, AVIRIS is an extraordinary sensor that delivers consistent images of high spectral sparkle in 224 adjoining spectral bands to have a wavelength variation between 400 to $2500 \mathrm{~nm}$. This extensively oscillating information helps in monitoring, measuring, and identifying vegetation index on the surface of the earth which is based on particle scattering and molecular captivation (Yichun Xie et al., 2008). To Collect multispectral imagery from the satellite cameras and getting it fused with UAV hyperspectral imagery can solve the vegetation index mapping but, the cloud cover could be a potential obstacle in the process (MicaSense, 2020).

\subsection{Hyperspectral Sensors}

Hyperspectral sensors allow data acquisition and processing selection for many UAV platforms (Wu et al., 2013) highlight four techniques for attaining computable data from the desired target. i.e., spectroscopy, multispectral imaging, RGB, and hyperspectral imaging. Additionally, (Sellar, et al., 2005) also describe that remote image sensing classifies based on their realized targets for spectral and spatial discrimination. Whereas, hyperspectral sensors can effectively capture a comprehensive map for spectral and spatial ranges (Raeva, et al., 2019). Conversely, RGB sensed data is incapable to deliver spectral signals outside the visible spectrum. Otherwise, essential for unfolding the physical and chemical assets of the object. 
Spectroscopy is a contiguity practice that is used to sense miniature objects such as leaf spots that obtain only spectral definitions of the targeted objects. Therefore, hyperspectral sensing is a preferred choice when both chemical and physical properties of the substances need studying.

\section{Field Applications}

\subsection{Soil and Field Mapping}

By utilizing hyperspectral imagery, Soil data is collected by UAVs before the planting of any crop which, gives farmers the existing position of the soil fertility, soil moisture, air and surface temperature, organic matter content, and water holding capacity of the soil. Crops get fertilization based on the data already collected from the field. The standing crops data also helps in monitoring the response of fertilization and other crop additives. The data collected from the Soil and farm help farmers to choose the best-suited planting patterns, planting schedule, quantities of seed, and manage the organic content of the soil. Moreover, the farmers become well informed about the necessary repairs and amendments that lead to getting better yield than the farmers growing their crops conventionally in their vicinity (P. Scull, 2003).

\subsection{Irrigation Management}

Water is a potential threat to future agriculture due to climate change and extreme weather events throughout the world. The need arises to utilize water resources effectively and wisely. UAVs can help farmers monitor and control irrigation schedules, especially while growing multiple crops on the same agricultural farm. Sensors get installed on the drippers and irrigation system whereas, any soil moisture variation is sensed by the ground sensors that allow the drippers to stop or start working. Another way is to link the entire irrigation system with the ground controller, and a single UAV flight can switch them on or off. Additionally, A UAV allows farmers to monitor irrigation practices remotely. Drones equipped with hyperspectral thermal cameras give you an exact amount of water needed for any field or the parts of the crop field that appear dry and needs water. This monitoring supports effective management to save a lot of water that can be used for growing extra crops on any farm (Quebrajo, et al., 2018), (Albornoz, 2017). 


\subsection{Crop Spraying}

The UAVs spraying capability is used for aerial spraying of insecticides, fertilizers, herbicides, and micro-fertilizers on the standing crops efficiently whenever required. Moreover, spot spraying is also possible if some disease or pests prevail on a few numbers of plants or some parts of the plants (HSE, 2016). UAVs can provide an immediate solution by spraying only the infested parts of such plants. Pre-emergence and post-emergence herbicide applications are also possible since UAVs can spray herbicide evenly near the surface. Similarly, liquid foliar fertilizers and micro-fertilizers practices give similar precision as in the herbicide and allow spot spraying due to the height management capability of a precision drone. Other advantages of aerial spraying include low volume spraying to avoid reaching the toxins to the soil surface to pollute it. These precise applications save input costs and time that otherwise wasted in deploying labor and putting extra cropping inputs conventionally (Xue X. et al., 2016), (Garre, 2018).

\subsection{Bulk Seed Casting}

The seeding for the small and medium-sized productions is equally beneficial for saving time and planting what is needed in the shortest possible planting periods. Usually, the majority of growers get a limited period between the harvesting of the standing crop and planting a new crop at the same piece of the land since such soils need a lot of cultural practices in this period. UAVs resolve both the selective and the bulk seed casting in the small and the medium size production by maintaining the desired planting distance in the shortest possible time with accuracy, effectively. Moreover, the UAVs are also capable of bulk tree seed casting in the forestation projects where human access denies. They can also be a potential tool for broadcasting seeds of annual or perennial grasses in the pastures or rangeland (Andrio, 2019).

\subsection{Crop Mapping and Surveying}

The UAVs have built-in equipment for carrying crop mapping and surveying on the types of terrain and changing weather conditions both for agriculture and livestock. UAVs bird-eye image helps the farmers to mark the outer boundaries of their cropped farms, besides monitoring the farm activities. UAVs' real-time footage can provide details of the infrastructure include differencing between crops, ponds, roads, and machinery at the farm. Moreover, they can provide the details of the covered areas with their measurements. Another positive aspect of UAVs surveying and crop mapping is that it quickly reflects the changes in infrastructure and 
cropping patterns easily, precisely. Weed detection is also possible using an autonomous flight within the cropped areas (Bah, 2017).

\subsection{Real-Time Monitoring}

This UAV feature allows the farmers to monitor real-time farm activities across the field and watching livestock in the graze lands. UAVs thermal imagery can detect every sort of movement on the farm and can help farmers monitor and control entire activities automated purposefully. Early pests and diseases detection is possible while monitoring crops using a UAV. Moreover, it can also help the growers to watch, and divert the movement of livestock if, they could have a little competency to fly agriculture drones for managing such activities. UAVs' real-time monitoring can also be used for watching the working and performance of the farm machinery with a single flight such as tractors, threshers, and harvesting efficiency of farm machinery whereas the additional automation can help the growers to watch the working of irrigation system and drippers performance. Installation of field sensors can allow the growers to check soil moisture content, $\mathrm{pH}$ values, and surrounding temperature, which leads to the complete automation of the entire farm practices (Kerkech, 2018), (Montero, 2018).

\section{Limitations}

One of the prime limitations for the small growers is interpreting the data collected by the UAVs. Technical advances such as software development and vehicle specifications are so rapid in the precision agriculture industry that the growers can't catch them within their timeframe. Some lighter UAVs are unstable in the wind that sometimes collects weak imagery that is not worth processing for the benefit of the UAV operators. It is more important to know that effective calibration needs specialized software, time, and knowledge to acquire data from variable altitudes and angles and may not be supported by some other software for processing and taking into account for acquisition. Moreover, the high initial investment is required for purchasing agriculture UAVs, while their flight endurance is limited between half an hour to one hour other than hybrid vehicles that can keep flying for two hours. 


\section{Conclusion}

Agriculture is moving towards sustainability and taking the shape of a modern enterprise. The adoption of precision farming is still slow due to high initial investment, grower's perception about the usefulness of these interventions, and doubtfulness about the credibility of UAVs and associated technologies, while most important is complicated use and unawareness among growers. It is likely to create awareness among small and medium-size growers about the advances in technology. And the responsibility lies on the shoulders of the manufacturers and operators. The operators need to provide them free trialing on small acreage irrespective of the crops and planting patterns and ascertain them that how useful and accurate their findings are, and how farmers could ease and benefit by implementing the precise decisions on planting and cultural practices of their crops. On the other hand, the UAV service providers need to incorporate agronomists, Entomologists, and soil scientists in their services support teams, instead of taking guidance from AI and backend algorithms, who could advise growers on the spot after taking observations through a UAV. Overall emphasis must be on imagery interpretation and calibration of the field sensors with backend data. The use of AI for automating the entire field practices and procedures could lead to boosting agriculture production for the small and medium growers, quickly. Whereas, UAV could play the role of mediator between the growers and precision farming. 


\section{REFERENCES}

1. FAO. Declaration of the World Summit on Food Security; FAO: Rome, Italy, 2009. J.V. Stafford, Implementing precision agriculture in the 21st century J. Agric. Eng. Res., 76 (3) (2000), pp. 267-275 https://doi.org/10.1006/jaer.2000.0577

2. Wright, M., 2016. West Coast winemakers get creative in how they grow waterintensive crops. PSFK. http://www.psfk.com/2016/02/drones-are-saving-thecalifornia-wine- industry.html.

3. Commission Delegated Regulation (EU) 2019/945 of 12 March 2019 on unmanned aircraft systems and on third-country operators of unmanned aircraft systems https://eur-lex.europa.eu/eli/reg_del/2019/945/oj

4. Commission Implementing Regulation (EU) 2019/947 of 24 May 2019 on the rules and procedures for the operation of unmanned aircraft https://eurlex.europa.eu/eli/reg_irmpl/2019/947/oj

5. Konert et al. / Advances in Science, Technology and Engineering Systems JournalVol. 5, No. 3, 93-99 (2020) https://doi.org/10.25046/aj050312

6. Mulla, D.J. Twenty five years of remote sensing in precision agriculture: Key advances and remaining knowledge gaps. Biosyst. Eng. 2013, 114, 358-371. https://doi.org/10.1016/j.biosystemseng.2012.08.009

7. Bauer, M.E.; Cipra, J.E. Identification of Agricultural Crops by Computer Processing of ERTS MSS Data; LARS Technical Reports; Purdue University: West Lafayette, IN, USA 1973; p. 20.5.

8. Mora, A.; Santos, T.; Lukasik, S.; Silva, J.; Falcao, A.; Fonseca, J.; Ribeiro, R. Land cover classification from multispectral data using computational intelligence tools: A comparative study. Information 2017, 8, 147.

https://doi.org/10.3390/info8040147

9. Zhang, C.; Kovacs, J.M. The a Zhang, C.; Kovacs, J.M. The application of small unmanned aerial systems for precision agriculture: A review. Precis. Agric. 2012, 13, 693-712. https://doi.org/10.1007/s11119-012-9274-5.

10. Manfreda, S.; McCabe, M.; Miller, P.; Lucas, R.; Pajuelo Madrigal, V.; Mallinis, G.; Ben Dor, E.; Helman, D.; Estes, L.; Ciraolo, G.; et al. On the use of unmanned aerial 
systems for environmental monitoring. Remote Sens. 2018, 10, 641.

https://doi.org/10.3390/rs10040641

11. Adão, T.; Hruška, J.; Pádua, L.; Bessa, J.; Peres, E.; Morais, R.; Sousa, J. Hyperspectral imaging: A review on UAV-based sensors, data processing and applications for agriculture and forestry. Remote Sens. 2017, 9, 1110. https://doi.org/10.3390/rs9111110

12. Maes, W.H.; Steppe, K. Perspectives for remote sensing with unmanned aerial vehicles in precision agriculture. Trends Plant Sci. 2019, 24, 152-164. https://doi.org/10.1016/j.tplants.2018.11.007

13. Yichun Xie, Zongyao Sha, Mei Yu, Remote sensing imagery in vegetation mapping: a review, Journal of Plant Ecology, Volume 1, Issue 1, March 2008, Pages 9-23 https://doi.org/10.1093/jpe/rtm005

14. Wu, D.; Sun, D.-W. Advanced applications of hyperspectral imaging technology for food quality and safety analysis and assessment: A review-Part I: Fundamentals. Innov. Food Sci. Emerg. Technol. 2013, 19, 1-14. https://doi.org/10.1016/j.ifset.2013.04.014

15. Sellar, R.G.; Boreman, G.D. Classification of imaging spectrometers for remote sensing applications. Opt. Eng. 2005, 44, 13602. https://doi.org/10.1117/1.1813441

16. Raeva, P.L.; Šedina, J.; Dlesk, A. Monitoring of crop fields using multispectral and thermal imagery from UAV. Eur. J. Remote Sens. 2019, 52, 192-201. https://doi.org/10.1080/22797254.2018.1527661

17. P. Scull, J. Franklin, O. Chadwick, D. McArthur Predictive soil mapping: a review Prog. Phys. Geogr., 27 (2) (2003), pp. 171-197 https://doi.org/10.1191/0309133303pp366ra

18. Quebrajo, L.; Perez-Ruiz, M.; Pérez-Urrestarazu, L.; Martínez, G.; Egea, G. Linking thermal imaging and soil remote sensing to enhance irrigation management of sugar beet. Biosyst. Eng. 2018, 165, 77-87.

https://doi.org/10.1016/j.biosystemseng.2017.08.013 
19. Albornoz, C.; Giraldo, L.F. Trajectory design for efficient crop irrigation with a UAV. In Proceedings of the 2017 IEEE 3rd Colombian Conference on Automatic Control (CCAC), Cartagena, Colombia, 18-20 October 2017; pp. 1-6. https://doi.org/10.1109/CCAC.2017.8276401

20. HSE (Homeland Surveillance and Electronics). 2016. Agriculture UAV crop duster sprayers. www.uavcropdustersprayers.com

21. Xue X ; Lan, Y.; Sun, Z.; Chang, C.; Hoffmann, W.C. Develop an unmanned aerial vehicle based automatic aerial spraying system. Comput. Electron. Agric. 2016, 128, 58-66.

https://doi.org/10.1016/j.compag.2016.07.022

22. Garre, P.; Harish, A. Autonomous Agricultural Pesticide Spraying UAV. In IOP Conference Series: Materials Science and Engineering; IOP Publishing: Bristol, UK, 2018; Volume 455, p. 012030. https://doi.org/10.1088/1757-899X/455/1/012030

23. Andrio, A. (2019). Development of UAV technology in seed dropping for aerial revegetation practices in Indonesia. IOP Conference Series: Earth and Environmental Science. 308. 012051. 10.1088/1755-1315/308/1/012051. https://doi.org/10.1088/1755-1315/308/1/012051

24. Bah, M.D.; Hafiane, A.; Canals, R. Weeds detection in UAV imagery using SLIC and the hough transform. In Proceedings of the 2017 Seventh International Conference on Image Processing Theory, Tools and Applications (IPTA), Montreal, QC, Canada, 28 November-1 December 2017; pp. 1-6 https://doi.org/10.1109/IPTA.2017.8310102

25. Kerkech, M.; Hafiane, A.; Canals, R. Deep leaning approach with colorimetric spaces and vegetation indices for vine diseases detection in UAV images. Comput. Electron. Agric. 2018, 155, 237-243. https://doi.org/10.1016/j.compag.2018.10.006

26. Montero, D.; Rueda, C. Detection of palm oil bud rot employing artificial vision. In IOP Conference Series: Materials Science and Engineering; IOP Publishing: Bristol, UK, 2018; Volume 437, p. 012004 https://doi.org/10.1088/1757-899X/437/1/012004 